DOI: https://doi.org/10.47405/mjssh.v5i6.425

\begin{tabular}{|c|c|}
\hline+5 & Malaysian Journal of Social Sciences and Humanities (MJSSH) \\
\hline Malaysian Journal of & Volume 5, Issue 6, June 2020 \\
\hline (MJ - SSH) & e-ISSN : 2504-8562 \\
\hline & $\begin{array}{l}\text { Journal home page: } \\
\text { www.msocialsciences.com }\end{array}$ \\
\hline
\end{tabular}

\title{
Relationship Between Financial Well-Being, Self-Esteem and Readiness for Marriage Among Final Year Students in Universiti Putra Malaysia (UPM)
}

\author{
Nur Amiratul Adibah Binti Ahmad Diah', Zanariah Binti Ismail1 \\ 1Department of Human Development and Family Studies, Faculty of Human Ecology, \\ Universiti Putra Malaysia (UPM)
}

Correspondence: Zanariah Binti Ismail (zanariah_i@upm.edu.my)

\begin{abstract}
The main purpose of this study was to determine the relationship between financial well-being, self-esteem, and readiness for marriage among final year students in University Putra Malaysia. There were a total of 148 final year students participated in this study where they were choosen by purposive sampling. The data were collected through a set of self-administered questionnaire. Incharge Financial Distress/Financial Well-Being was used to determine financial well-being. Rosernberg Self-Esteem Scale was used to measure self-esteem. Criteria for Marriage Readiness Questionnaire was used to measure readiness for marriage. The finding demonstrated that financial well-being and readiness for marriage was negatively correlated $(r=-.187, p=.023)$ while gender, parents" marital status, and self-esteem did not have any correlation with readiness for marriage. Findings of this study suggest that strong financial well-being is important for someone is ready to get married. It is recommended for future research to take account of the other predictive factors for readiness for marriage among emerging adulthoods. Furthermore, future research could be expanded in various universities in Malaysia with increased sample size in order to provide greater generalization and yield a more reliable data.
\end{abstract}

Keywords: financial well-being, marriage, readiness, self-esteem

\section{Introduction}

Arnett (2001) stated that marriage is not only event that unites two people with their family in a relationship with a variety of mutual obligations, it is also the event that marks the attainment of adult status. For young people, they perceive their own and their partner's readiness for marriage is by completing the school and being established in job areas is associated with the timing of marriage for both of the women and men (Carroll et al., 2009). On the other hand, marital readiness is defined as perceiving the self as ready for marriage, should the partner be selected (Mosko \& Pistole, 2010). Finance remain one of the top reasons for the dissoultion of marriages, yet they are rarely discussed (Muhammad, 2014). Overall, in this study will focus on financial well-being of a student because well - being is the subjective perception of one"s personal situation (Judge, Ilies, \& Dimotakis 2010; Lee et al. 2002). Self-esteem appears to be an important contributing factor related to relationship quality and marital readiness (Sciangula \& Morry, 2009). It indicates the extent to which an individual believes himself or herself to be competent and worthy of living (Malhi \& Reasoner, 2000). 
The divorce rating was rising between married couple. According to Datuk Che Mat Che Ali, Director General of JAWI, mostly young couples who were under 30 years old divorced because lack of preparation in the responsibilities of marriage, especially involving financial matters and family interventions. Therefore, it is important to study about the level of readiness for marriage especially for emerging adulthood before they enter the real marriage life.

Readiness for marriage has received little attention in the research literature although along with feeling and attitudes about marriage is a key variable in the decision to marry and a significant predictor of later marital satisfaction (Carroll et al., 2009; Holman, Larson \& Harmer, 1994). Besides that, based on Dixon Model, there are three sets of factors to explain the age of marriages. There were availability of mates, feasibility of, and the desirability of marriage.

Availability of mates means the influence of peers, which covered number of potential spouses and the types of mate selection practiced. While the feasibility means economic affordability. It covered not only the daughter's economic obligation to their own families, but also included the desire for higher living standard. The desirability of marriage could be simply expressed as the willingness to get marry. Thus the current study tried to identify the economic affordability of the final year student by knowing their current financial well-being. Therefore, the level of readiness towards marriage can be predicted. There are two hypotheses for this current study:

Ho1: There is no significant relationship between financial well-being and readiness for marriage.

Ho2: $\quad$ There is no significant relationship between self-esteem and readiness for marriage.

\section{Literature Review}

\section{Readiness for marriage}

From past researched, there still little known about the factors that influence an individual"s perception of whether or not he or she is getting married. According to Carroll et al. (2009), in examining the transition from emerging adulthood to young adulthood has emphasized there is the need to better understand the developmental processes of how young people make commitments to adults system such as marriage. Carroll et al. (2009) also stated that emerging adults form marriage philosophies consisting of the degree they desire to marry, the ideal age at which they would like to get married, the type of person they would like to marry, and their sense of personal readiness for marriage. When they achieved all these conditions, then they will ready to enter the marriage life.

\section{Financial well-being with readiness for marriage}

One of the important answers when people are asking about when you are getting married is waiting until the financial is stable. Considering how many couples fight and get divorced over money, most of the people put financial stability very high on their list of pre marriage requirements. Finance remain one of the top reasons for the dissolution of marriages, yet they were rarely discussed (Muhammad, 2014). But, past study had found that there was significant relationship between financial well-being with marital satisfaction (Thoresen \& Goldsmith, 1987). Past study also had looked into women"s perception and experienced at marriage which had altered due to movement and economic changes. Aronson (2008) stated that the couple with high rate of divorce is due to economic insecurity. Both women and men are necessary to be financial stable so that they are being able to support themselves. When the finance is stable, they will achieve their financial well-being. 


\section{Self-esteem with readiness for marriage}

Self-esteem research generally has focused on global self-esteem that is one"s feelings of selfworth which means the degree to which individuals feel positive about themselves, that is they feel that they are good and valuable (Stets \& Burke, 2014). Past research stated that, we prefer positive self-evaluations because it indicates our social worth in which they satisfy our desire for communion and interpersonal connectedness with others (Swann \& Bosson, 2010). One study had found that self-esteem was necessary component in starting and maintaining romantic relationship (Eryilmaz \& Atak, 2011). They had found a positive relationship between starting romantic intimacy and the level of self-esteem in an individual. This indicates that self-esteem is a factor in romantic relationship, including marriage. Furthermore, other study had found that self-esteem was necessary component in starting and maintaining romantic relationship (Eryilmaz \& Atak, 2011). They had found a positive relationship between starting romantic intimacy and the level of self - esteem in an individual. This indicates that self-esteem is a factor in romantic relationship, including marriage.

\section{Methodology}

\section{Research Design}

This study will be conducted by using correlational research design. In addition, this study will also use a cross-sectional research design because it is only short term research that may be last for three months only. This study also will use quantitative method involving survey questionnaires to collect the quantitative data. Final year students in University Putra Malaysia will be given self- administered questionnaires that include background of respondent, InCharge Financial Distress / Financial Well -Being Scale (IFDFW) to personalized assessment of one"s financial health, Rosernberg Self-Esteem Scale to measure one"s self-esteem, and Criteria for Marriage Readiness Questionnaire (CMRQ) to measure the readiness for marriage.

\section{Sampling Technique}

Purposive sampling method is used to select the sample in this study. Purposive sampling technique is utilized because researcher need to ask each person the age and also the status which is still single or have been married because this study need a final year student of 23 years old and do not married yet.

\section{Instrumentation}

This study have build a questionnaire consist of four section which are; Section A for respondent background, Section B for financial well-being (InCharge Financial Distress / Financial WellBeing Scale), Section C for self-esteem (Rosernberg Self Esteem Scale), and Section D for readiness for marriage (Criteria for Marriage Readiness Questionnaire).

\section{Section B-InCharge Financial Distress / Financial Well-Being Scale (IFDFW)}

This instrument is to personalized assessment of one"s financial health and developed by Prawitz et al. (2006). It consist of eight items, four items that represented a sense of one"s present state of financial well-being and four items that characterize done"s reaction to his or her present state of financial well-being. The reliability is higher which is 0.956 . There are ten scoring in this scale which is starting from one is the lowest financial well-being, followed by extremely low financial well-being, very poor financial well-being, poor financial well-being, average financial wellbeing, moderate financial well-being, good financial well-being, very good financial well-being, extremely high financial well-being, and ten refer to highest financial well-being. Respondents 
who score higher level of financial well-being would result in highly financial health which means lower level financial distress in IFDFW would result in higher scores on the scale.

\section{Section C-Rosernberg Self-Esteem Scale}

This instrument is developed by Rosernberg in 1965 which comprised of 10 items. It is used to assess global self-esteem, which is higher scores indicate more positive self-regard. Each item was responded with 4 - point Likert scale ranging from strongly agree to strongly disagree. The scale generally has high reliability, with test - retest correlations value between 0.82 and 0.88 . From all ten items, there are five items that are negative items. The negative items need to be recode when analysis data is need to be done. Item that need to be recode is item 2, 5, 6, 8, and 9 .

\section{Section D - Criteria for Marriage Readiness Questionnaire (CMRQ)}

This instrument is developed by Carroll et al. (2009) to measure the readiness for marriage among adolescence. It consist 57 scales items and the reliability is 0.86 . This instrument has six factors of criteria which are norm compliance (i.e. avoid becoming drunk, crime), family capacities (i.e. become capable of running household), role transitions (i.e. financially independent, purchase a house), interpersonal competencies (i.e. able to express feelings), intrapersonal competencies (have good controls of emotions), and sexually experienced (i.e. have had considerable sexual experience). It also contains six non - scaled items which are reached age 18 , reached age 21 , reached age 25 , reached 30 , able to pay for wedding, and marriage preparation course.

From all the 57 items, there are only 42 questions are used in this study which consist 39 positive items and 3 negative items that need to be recode when analyze. Several items are deleted because this scale is developed in Europe, therefore some of the statement may consider the factor of norm and value of the society and religion in this country.

\section{Data Analysis}

Data are analyzed by using the Statistical Package for Social Science (SPSS) program through inferential statistics. Pearson"s Correlation analysis is used to test the null hypothesis and analyzed correlation between the independent variables, financial well-being and self-esteem and also the dependent variable which is readiness for marriage.

\section{Findings}

Pearson Correlation Test was carried out to determine the relationship between independent variables of financial well-being and self-esteem with readiness for marriage. These findings carried out based on the two hypotheses Hol and Ho2. The findings of study were shown in Table 1.

Based on the analysis, there is a meaningful negative relationship between financial well-being and readiness for marriage $(r=-.187, p<0.05)$. Negative values of financial well-being represent low financial distress indicate to high marital readiness. Thus, the hypothesis is rejected. Correspond to the past research showed that there was significant relationship between financial well-being and marital satisfaction (Thoresen \& Goldsmith, 1987). Even though there was no direct significant between these two variables, but there was supported that marital readiness is an important predictor of later marital satisfaction (Holman, Larson \& Harmer, 1994).

Table 1: Pearson correlation

\begin{tabular}{lll}
\hline Variables & Readiness for marriage \\
\cline { 2 - 2 } & $\mathbf{p}$ \\
\hline
\end{tabular}


DOI: https://doi.org/10.47405/mjssh.v5i6.425

\begin{tabular}{lll}
\hline Financial well-being & $\mathbf{- . 1 8 7 *}$ & $\mathbf{. 0 2 3}$ \\
Self - esteem & $\mathbf{- . 0 9 0}$ & $\mathbf{. 2 7 9}$
\end{tabular}

* Correlation is significant at the 0.05 level $(2$ - tailed $)$

From the analysis, there is no significant relationship between self-esteem and readiness for marriage $(r=-.090, p=.279)$. Therefore, self-esteem do not influence the readiness for marriage among final year students. Thus, hypothesis is failed to reject. This findings consistence with the past research which is self-esteem alone did not make a statistically significant to marital readiness criteria (Gunnels, 2013).

\section{Conclusion And Recommendations}

The finding of this study is to give awareness for students especially in their final year about marital readiness so that they can be well prepared before entering marriage life. In order to know that they are ready or not in getting married, they should give attention to the criteria of marriage readiness such as from the aspect of family capacities, role transitions, interpersonal and intrapersonal competencies. When the aspect is fulfill, they may decide to get married soon.

Furthermore, this issue should be given more attention by the authorities because the finding of this study is to give some important information towards university, educators, and government regarding readiness for marriage among undergraduates population. For university, they may conduct programs of marital readiness among students while for government, they may improve marriage empowerment programs by promote importance of preparation before marriage to strengthen family institution Moreover, this study has bring better understanding for emerging adults especially students in their final year view the criteria for marriage readiness and other factors that may lead to someone is ready to get married. However, this study has been given little attention by researcher. Future research should address what more factors that may lead to readiness for marriage besides their financial and self-esteem. They may focus on parent-child relationship perception in marriage readiness.

The most apparent limitation in this study is the number and diversity of the respondents. The total of the respondent in this study is not achieving the standardize from Krajcie and Morgan table. So, it gives a big effect for the results of this study especially in hypothesis testing. Future research should have greater number of respondent in order to have significant results and minimize the error in the study. This study also lack in diversity especially the race and gender. The sample consisted majority of Malay student and female student. Future studies should include more race diverse population and balance the total of male and female respondents. Another limitation is, this study focused only for final year students in University Putra Malaysia only. Future studies would have greater benefit if they gather a sample of students from local universities in Malaysia in order to get their full perception towards marriage readiness.

\section{Acknowledgements}

We would like to thank the respondents of this study for their cooperation.

\section{References}

Arnett, J. J., (2001). Conceptions of the transition to adulthood: Perspectives from adolescence through midlife. Journal of Adult Development, 8(2), 133 - 143.

Aronson, P. (2008). The markers and meanings of growing up: Contemporary young women's transition from adolescence to adulthood. Gender and Society, $56-82$. 
Carroll, J. S., Badger, S., Willoughby, B. J., Nelson, L. J., Madsen, S. D., \& Barry, C. M. (2009). Ready or not?: Criteria for marriage readiness among emerging adults. Journal of Adolescent Research.

Eryilmaz, A., 7 Atak, H. (2011). Investigation of starting romantic intimacy in emerging adulthood in terms of self - esteem, gender, and gender roles. Educational Sciences: Theory \& Practice, 11(2), $595-600$.

Gunnels, M. J. (2013). The impact of self - esteem and religiosity on the marital readiness criteria of college students. H.onors Theses. The University of Southern Mississippi.

Holman, T. B., Larson, J. H., \& Harmer, S. L. (1994). The development and predictive validity of a new premarital assessment instrument: The preparation for marriage questionnaire. Family Relations, 43, 46-52.

Judge, Timothy A., Remus Ilies, \& Nikolaos Dimotakis. (2010). Are health and happiness the product of wisdom? The relationship of general mental ability to educational and occupational attainment, health, and well-being. Journal of Applied Psychology, 95 (3), 454-468.

Lee, Dong-Jin, M. Joseph Sirgy, Val Larsen, \& Newell D. Wright. (2002). Developing a subjective measure of consumer well - being. Journal of Macro - marketing, 22 (2), 158169.

Malhi, R. S., \& Reasoner, R. W. (2000). Enhancing self-esteem. Kuala Lumpur: Self - esteem Seminars Sdn. Bhd.

Mosko, J. E., \& Pistole, M. C. (2010). Attachment and religiousness: Contributions to young adult marital attitudes and readiness. The Family Journal, $128-135$.

Muhammad, D. (2014). American money: love, finance, and preparing for marriage. The Crisis, pg 52.

O'e Neill, B., Prawitz, A.D., Sorhaindo, B., Kim, J., \& Garman, E.T. (2006). Changes in health, negative financial events, and financial distress / financial well - being for debt management program clients. Journal of Financial Counseling and Planning, 17(2), 46-63.

Rosernberg, M. (1965). Society and the adolescent self - image. Princeton, NJ: Princeton University Press.

Sciangula, A., \& Morry, M. M. (2009). Self - esteem and perceived regard: How I see myself affects my relationship satisfaction. Journal Of Social Psychology, 149(2), $143-158$.

Stets, J. E., \& Burke, P. J. (2014). Emotions and identity non - verification. Social Psychology.

Stinnett, N. (1969). Readiness for marital competence. Journal of Home Economics, 61, 683686.

Swann, W. B., Jr., \& Bosson, J. K. (2010). Self and identity. Social Psychology, 589 -628.

Thoresen, R. J., \& Goldsmith, E. B. (1987). The relationship between army families" financial well - being and depression, general well - being, and marital satisfaction. The Journal of Social Psychology, 127(5), 545 - 547. 